\title{
Relationship between telomere dynamics and movement and behavior during winter in the thick-billed murre
}

\author{
Rebecca C. Young ${ }^{1, *}$, Rachael A. Orben ${ }^{2}$, Alexis P. Will ${ }^{1}$, Alexander S. Kitaysky ${ }^{1}$ \\ ${ }^{1}$ Department of Biology and Wildlife, Institute of Arctic Biology, University of Alaska Fairbanks, Irving 311, Fairbanks, \\ AK 99775, USA \\ ${ }^{2}$ Department of Fisheries and Wildlife, Oregon State University, Hatfield Marine Science Center, 2030 SE Marine Science Dr., \\ Newport, OR 97365, USA
}

\begin{abstract}
Connecting the life history stages of the annual cycle via carry-over effects crucially informs estimates of mortality and reproduction. This study explores variables linking the breeding and wintering seasons in a pursuit-diving seabird, the thick-billed murre Uria lomvia. We deployed global location sensing loggers on chick-rearing murres breeding in the southeastern Bering Sea to examine subsequent overwinter locations and foraging behavior. In the tracked individuals, we measured individual telomere length and longitudinal telomere length changes in blood and used feathers molted during fall and early spring to assess trophic niche (via stable isotopes) and stress levels (as reflected in feather corticosterone levels). Longitudinal changes in telomere length were better predicted by winter diving parameters than by geographic distribution and movement variables, such that birds that foraged more intensely (more time diving, more dive bouts) also experienced higher telomere loss. This indicates that in a pursuit-diving species with high flight costs, patterns of water-column use through diving may be more important than horizontal spatial movement for predicting physiological changes underlying carry-over effects. We conclude that telomere dynamics might be used as an indicator connecting behavior and physiological stress from season to season.
\end{abstract}

KEY WORDS: Telomeres - Carry-over effects $\cdot$ Feather corticosterone $\cdot$ Stable isotope analysis Migration · Thick-billed murre $\cdot$ Uria lomvia $\cdot$ Wintering grounds $\cdot$ Geolocator

\section{INTRODUCTION}

Carry-over effects are often important drivers of population processes, including individual reproductive success, especially in migratory animals (Norris \& Taylor 2006, Holmes 2007, Morrissette et al. 2010). These effects describe situations in which fitnessrelated outcomes in one season are affected by success or state in a previous season $\left(\mathrm{O}^{\prime} \mathrm{Connor}\right.$ et al. 2014). Many carry-over effect studies describe how quality of winter habitat and diet affect phenology and reproductive success of subsequent breeding seasons (Reudink et al. 2009, Sorensen et al. 2009,

*Corresponding author: rebeccacyoung721@gmail.com

${ }^{\S}$ Advance View was available online February 22, 2017
Drake et al. 2013), while others describe effects of the breeding season on the non-breeding period (Stutchbury et al. 2011, Schultner et al. 2014b). However, the proximate physiological changes that accompany these effects are not as well studied.

One of the strongest components of carry-over effects is quality of the winter environment. Winter habitat choice (Reudink et al. 2009, Inger et al. 2010, Angelier et al. 2013, González-Prieto \& Hobson 2013) and diet (Sorensen et al. 2009) can strongly influence performance and condition during subsequent breeding seasons. At the same time, quality and dominance status may influence access to wintering habi-

() The authors 2017. Open Access under Creative Commons by Attribution Licence. Use, distribution and reproduction are unrestricted. Authors and original publication must be credited. 
tat (Rockwell et al. 2012, Angelier et al. 2013), so that these effects may be a combination of extrinsic (environmental) or intrinsic (reflecting individual quality through habitat access) factors. Some studies indicate that these carry-over effects are mediated interseasonally by glucocorticoid stress hormones (Sanderson et al. 2014), levels of which elevate in response to poor environment or low food availability. For example, elevated corticosterone in blood plasma indicates nutritional stress in common murres Uria aalge (Kitaysky et al. 2007).

In this study, we use physiological measures and biologging to explore the relationship between variables associated with the non-breeding period (wintering variables) and inter-annual telomere dynamics in the thick-billed murre $U$. lomvia (hereafter murre). We deployed geolocation and depth loggers to track murre location and diving behavior during migration and wintering in the North Pacific (Orben et al. 2015). As habitat use may change within the wintering period (e.g. Takahashi et al. 2015), we also compare diet and stress variables measured in plumage molted during fall and spring. Stable isotope values in feathers reflect diet during the molt in which they were grown (Becker et al. 2007, Bourgeon et al. 2014). Specifically, stable isotope values for nitrogen (ratios of ${ }^{15} \mathrm{~N} /{ }^{14} \mathrm{~N}$ as compared to an international standard; $\left.\delta^{15} \mathrm{~N}\right)$ provide a proxy for the trophic level of foraging (Karnovsky et al. 2012), which may influence reproductive parameters via carry-over effects (Sorensen et al. 2009). During the breeding season, murres at our study colonies eat a mixture of prey including invertebrates (squid and euphausiids) and fish (especially juvenile pollock Gadus chalcogrammus) (Harding et al. 2013). In general, higher trophic-level prey (i.e. fish) are a higher-quality food source, since they have high protein and fat content and do not require energy expenditure to excrete excess salt (Nehls 1996). Thus, a diet of high-quality, high trophic-level prey may contribute to recovery from the breeding season. Fish and squid may also require more skill to catch, since they are active swimmers which must be pursued (Kokubun et al. 2016). Therefore, access to this high-quality prey may be more dependent on diving skills than patterns in spatial use.

Telomeres are non-coding DNA repeats which cap eukaryotic chromosomes and function to protect DNA (Monaghan \& Haussmann 2006). Degradation of telomeres occurs when cells divide, and loss rates are accelerated by oxidative damage (von Zglinicki 2002). Telomere length (TL) is considered a potential indicator of individual state or quality and is increas- ingly used in ecology as an indicator of biological age (Monaghan \& Haussmann 2006, Barrett et al. 2013). Short TL and loss of TL may be related to variation in migration distance (Plot et al. 2012), elevated breeding stress (Schultner et al. 2014a), lower survival (Salomons et al. 2009, Barrett et al. 2013), or poorquality wintering habitat (Angelier et al. 2013), making telomere dynamics a good candidate for reflecting patterns in carry-over effects. TL loss has also been used as a cost of reproduction in avian systems (Bauch et al. 2013, Sudyka et al. 2014). However, there are still many links to be made between telomere dynamics, individual quality, and survival (Monaghan 2010). Some studies, especially of longlived species, have not found relationships with longevity (Pauliny et al. 2006) or changes in body mass and survival (Pauliny et al. 2012). In thick-billed murres, TL is related to physiological stress (baseline corticosterone) (Young et al. 2016) and interacts with habitat quality to predict patterns in foraging behavior during the breeding season (Young et al. 2015). Links to other phases of the annual cycle, however, have not been tested.

The stress hormone corticosterone is passively deposited into feathers as they are grown; thus, the concentration of corticosterone in feathers acts as an integrated measure of stress experienced during feather growth (Bortolotti et al. 2008, Lattin et al. 2011). Feather corticosterone (fCORT) is linked to use of high-quality wintering grounds during migration in great skuas Stercorarius skua (Bourgeon et al. 2014), overwinter survival in house sparrows Passer domesticus (Koren et al. 2012), and nutritional stress in rhinoceros auklets Cerorhinca monocerata (Will et al. 2015). Our use of feathers from 2 parts of the body allows evaluation of stress levels in fall and in spring.

This study addresses the relationship between TL and change and wintering variables. Wintering variables included diving variables (average dive depth, dive bouts per day, and a measure of foraging intensity), spatial variables (winter home range area and maximum distance from colony), fall and spring fCORT, and fall and spring $\delta^{15} \mathrm{~N}$ values. We test (1) the effect of TL (in year 1) on wintering variables; (2) the effect of wintering variables on the annual change in TL ( $\Delta \mathrm{TL})$; and (3) the possible effects of TL, $\Delta \mathrm{TL}$, and wintering variables on subsequent breeding probability. We predict that TL will explain variation in wintering variables, indicating more effort (e.g. high fCORT, large winter home range, high foraging intensity) or lower foraging ability (lower $\delta^{15} \mathrm{~N}$ values) in birds with short TL (Prediction 1). TL may act as an integrative measure of individual state 
(Monaghan \& Haussmann 2006, Barrett et al. 2013), so this prediction describes a carry-over effect by which accumulated life history may affect behavior in the upcoming winter. Second, we test the relationships between wintering behaviors and $\Delta \mathrm{TL}$. Murres have some of the most energetically expensive avian flight (Elliott et al. 2013), but their wing-propelled pursuit-diving behavior allows them to exploit the oceanic environment in a third dimension, diving to depths of over $200 \mathrm{~m}$ (Orben et al. 2015). We predict that diving behaviors will be more important predictors of telomere changes than spatial variables (e.g. winter home range area, maximum distance from colony) (Prediction 2). Third, we test for a relationship between wintering variables and subsequent breeding. If telomeres mediate carry-over effects, then wintering variables associated with TL will be associated with subsequent breeding (Prediction 3). We also directly test the effect of TL in deployment year and TL change between years on breeding probability.

\section{MATERIALS AND METHODS}

\section{Field sampling}

Geolocation loggers and time-depth recorders (LAT2500 and LAT1500, Lotek Wireless) were deployed on breeding thick-billed murres during July and August of 2008 and 2009 at 2 of the Pribilof Islands (St. Paul Island: $57^{\circ} 10^{\prime} \mathrm{N}, 170^{\circ} 17^{\prime} \mathrm{W}$; and St. George Island: $56^{\circ} 34^{\prime} \mathrm{N}, 169^{\circ} 36^{\prime} \mathrm{W}$ ) and at Bogoslof Island in 2008 only $\left(53^{\circ} 55^{\prime} \mathrm{N}, 168^{\circ} 02^{\prime} \mathrm{W}\right.$ ) (Orben et al. 2015). The colonies are located in the southeastern Bering Sea, Alaska, and murres at all 3 colonies conduct short-distance migrations, either in the vicinity of the colonies or nearby in the western Bering Sea, Gulf of Alaska, or North Pacific (Orben et al. 2015). Loggers were retrieved 1 to 2 yr after deployment $(\mathrm{n}=49)$, also in July and August, and blood samples and measurements were taken again. Most birds ( $\mathrm{n}=39$ ) were blood sampled in both years, allowing calculation of $\Delta \mathrm{TL}$. Of the remaining 10 birds, 9 were only sampled in the year of device deployment, and 1 was only sampled in the year of retrieval. Blood samples $(<0.5 \mathrm{ml})$ were taken from the wing vein, preserved in a $2 \%$ EDTA buffer, and stored at the University of Alaska Fairbanks in a glycerol storage buffer at $-80^{\circ} \mathrm{C}$. Body size was calculated as a principal component of wing, tarsus, and culmen measurements. Principal component 1 (PC1) explained $51 \%$ of the variation, and all 3 variables were negatively correlated with PC1 (mean: $-0.72 \pm$ 0.01), so the inverse PC1 score was used as body size.

\section{Geolocation and diving data}

Geolocator data were analyzed as in Orben et al. (2015). After filtering erroneous locations, we used a generalized additive model to smooth latitude and longitude over time. Winter home range area was calculated as the minimum convex hull area of high residency time based on a radius of $60 \mathrm{~km}$. High residency locations were identified as the upper quartile of residence time for each murre (Orben et al. 2015). Loggers recorded pressure conditionally every minute below 5 dbar $(5 \mathrm{~m})$. Using maximum likelihood estimates, dive bout end criteria were calculated for each murre (DIVEMOVE 1.3.4; Luque \& Guinet 2007), and dives were separated into bouts when 25.7 min occurred between dives (Orben et al. 2015). Migration and diving were analyzed at either the annual level (e.g. maximum distance from the colony) or the seasonal level (e.g. fCORT levels in fall or spring). Seasonal divisions were as follows: fall = September, October, November; winter = December, January, February; and spring = March, April, May. Diving variables of interest were the percent of the day spent diving, bout duration, dives per bout, and percent of the bout diving. These variables were all positively correlated (mean correlation $=0.53$, mean variance inflation factor $=17.9$ ), so they were collapsed into 1 foraging intensity variable using a principal component analysis. The variance explained by PC1 was $65 \%$, and all factors had strong positive loadings (Table 1).

\section{Laboratory techniques}

Telomeres were measured using the telomere restriction fragment assay following Young et al. (2015). Briefly, $5 \mu$ l of packed red blood cells were extracted

Table 1. Measures of thick-billed murre foraging intensity. Variable loadings and correlations from the first principal component of a principal component analysis

\begin{tabular}{|lcc|}
\hline Variable & Loading & Correlation \\
\hline Percent of 24 h diving & 1.38 & 0.768 \\
Bout duration & 1.47 & 0.819 \\
Dives per bout & 1.73 & 0.963 \\
Percent of the bout diving & 1.16 & 0.646 \\
\hline
\end{tabular}


into agarose plugs using the Chef Genomic DNA Plug Kit (Bio-Rad). DNA was separated on a $0.8 \%$ agarose gel using pulsed field gel electrophoresis. TL values were calculated from gel images following Salomons et al. (2009) and Young et al. (2015). Longitudinal samples from the same individual were analyzed in adjacent lanes, and gels included 2 control samples per gel to determine intra-assay variability $(\mathrm{CV}=$ range/mean; mean $\mathrm{CV}=4.7 \pm 1.4 \%)$. TL values were standardized to these control samples to reduce the potential effects of inter-assay variability.

For $\delta^{15} \mathrm{~N}$ and fCORT analyses, we sampled breast feathers grown in the autumn and throat feathers from breeding plumage grown in February and March (Gaston \& Jones 1998). Stable isotope values were analyzed using a Carlo-Erba elemental analyzer interfaced with a Finnigan Delta Plus XP mass spectrometer (Light Stable Isotope Lab, University of California Santa Cruz [UCSC]). Measurement precision (standard deviation), based on within-run replicates of the laboratory standard (pugel), was $0.14 \%$. Fall and spring $\delta^{15} \mathrm{~N}$ values were not correlated (correlation $=0.261,95 \% \mathrm{CI}=-0.028$ to 0.51 ). For fCORT assays, throat ( 3 feathers) and breast (1 feather) feathers were weighed to the nearest $\mathrm{mg}$ and measured to the nearest $0.5 \mathrm{~mm}$. Throat feathers were measured separately but were weighed together (Lattin et al. 2011). We followed methods outlined in Bortolotti et al. (2008) but did not mince feathers. Feathers were extracted in $5 \mathrm{ml}$ of HPLCgrade methanol (Fisher Scientific), sonicated for $60 \mathrm{~min}$ at $50^{\circ} \mathrm{C}$, and incubated overnight in a $50^{\circ} \mathrm{C}$ water bath. Whole feathers were analyzed in a single radioimmunoassay (Wingfield \& Farner 1975) using a Sigma-Aldrich antibody (C8784) with an intra-assay CV < $1 \%$. Samples were combined with $2000 \mathrm{cpm}$ of tritium-labeled corticosterone (NET399, Perkin Elmer) to control for loss of hormone during analysis. Final fCORT titers were adjusted for percent recovery (mean 95\%). Results were converted

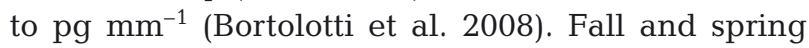
fCORT values were correlated (correlation $=0.50$, $95 \% \mathrm{CI}=0.19-0.71$ ), indicating that a murre stressed in the fall is also likely to incur high stress in the spring.

\section{Analysis}

Analysis was conducted in program R (R Development Core Team 2011). Prediction 1 was addressed using MANOVA, in which TL was the independent variable, and dependent variables were a subset of the wintering variables (foraging intensity, maximum distance from the colony, winter home range area, fall $\delta^{15} \mathrm{~N}$ values, spring $\delta^{15} \mathrm{~N}$ values, fall fCORT levels, and spring fCORT levels). Only 29 birds had data for each of these variables and could be included in the MANOVA. As fall fCORT demonstrated an effect in the larger analysis, a follow-up univariate ANOVA with a larger sample size $(\mathrm{n}=$ 34) was also run for this variable. For Predictions 2 and 3, models used the ' $\mathrm{lm}$ ' function in $\mathrm{R}$ and were compared using Akaike's information criterion corrected for small sample size (AICc). For Prediction 2 , the models were $\Delta \mathrm{TL} \sim \mathrm{X}$, where $\Delta \mathrm{TL}$ was the percent change in TL from deployment to recapture, and $\mathrm{X}$ was wintering variables. $\Delta \mathrm{TL}$ was usually calculated from 1 yr to the following year, but in 4 cases telomeres were re-sampled after $2 \mathrm{yr}_{\text {; }}$ in these cases, $\Delta$ TL was divided by 2 to indicate mean annual change. In addition to wintering variables, we include other measures likely to affect migration and TL: year (of global location sensing deployment, first capture), sex (Young et al. 2013, 2015), colony (Young et al. 2015), body size (Barrett et al. 2013, Orben et al. 2015), body mass, and the annual change in body mass. Twenty-three birds had complete data and could be used in this analysis. The variables which most strongly limited sample size were the fall and spring $\delta^{15} \mathrm{~N}$ values, so a secondary analysis was done which excluded these variables but increased the sample size $(\mathrm{n}=31)$.

We addressed Prediction 3, the effect of wintering variables on breeding in the following year, using logistic regression. Wintering variables included maximum distance from the colony, winter home range area, fall and spring $\delta^{15} \mathrm{~N}$ values, fall and spring fCORT, and foraging intensity. Telomere variables were deployment TL and $\Delta \mathrm{TL}$. We also tested the effect of deployment year, sex, colony, change in body mass from year 1 to year 2, and body size. Twenty-one birds had complete data and could be used in this analysis. Birds were recaptured at breeding sites, so birds recaptured as 'not breeding' were likely birds that failed very early in breeding or were attending nest sites but deferred reproduction. Thus, non-breeding recaptures represented birds that survived the winter but were unable or unwilling to successfully breed. We could not distinguish between birds that were not breeding due to high stress levels or poor condition and those that may have failed for extrinsic reasons; however, even in years with a high reproductive failure due to extrinsic causes, poor parental condition may still play a large role in determining which nests fail. 


\section{RESULTS}

\section{Effect of deployment TL on wintering variables (Prediction 1)}

A MANOVA in which TL was tested against foraging intensity, maximum distance from the colony, winter home range area, fall $\delta^{15} \mathrm{~N}$ values, spring $\delta^{15} \mathrm{~N}$ values, fall fCORT, and spring fCORT was not significant (Pillai $=0.31, F_{7,21}=1.33, \mathrm{p}=0.28$ ). However, the univariate ANOVAs indicated that fall fCORT may be positively related to TL $\left(F_{1,27}=6.0, \mathrm{p}=0.021\right)$. A follow-up univariate ANOVA, which used a larger sample size to test the relationship between fall fCORT and TL $(n=34)$, also demonstrated the positive relationship (Fig. 1 ; $\beta=4.35 \times 10^{-4} \pm 1.82 \times 10^{-4}$ ).

\section{Annual and seasonal predictors of telomere change (Prediction 2)}

We tested the effects of wintering variables on longitudinal $\Delta \mathrm{TL}$. Models making up 95\% of AICC weight are presented in Table 2. Parameter estimates were model-averaged using these models (Table 3). The only parameter with an estimate that did not overlap zero was foraging intensity. Foraging intensity showed a negative relationship with $\Delta \mathrm{TL}$ (Fig. 2), such that birds that foraged more intensively (more time spent diving, more dive bouts) lost more TL.

In the larger analysis, without stable isotope values, models making up $95 \%$ of AIC weight were foraging intensity, year, null, maximum distance from colony, sex, and body size. Foraging intensity remained the best model $(\triangle \mathrm{AICC}=0)$, with the second

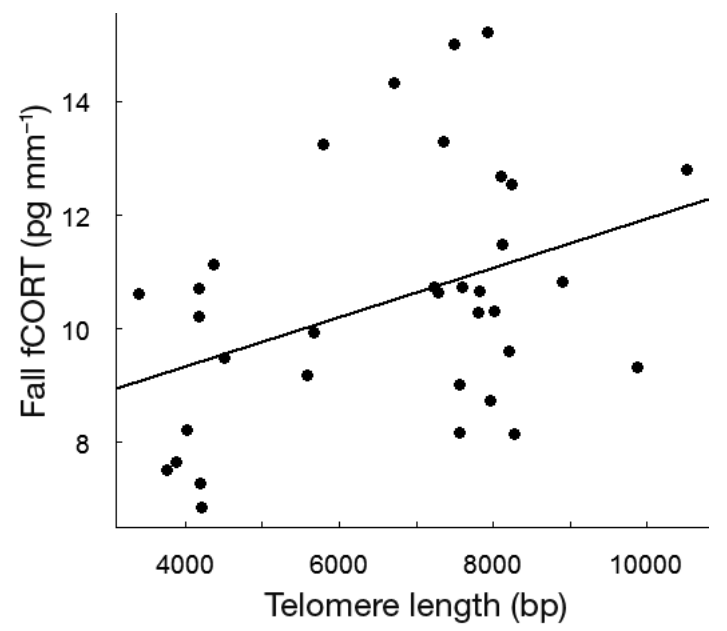

Fig. 1. Deployment (breeding season) telomere length predicting feather corticosterone (fCORT) levels in thick-billed murres, as measured in feathers grown during the fall
Table 2. Akaike's information criterion corrected for sample size (AICC) output for models of wintering variables (as predictors) and change in telomere length (response variable in the thick-billed murre). Presented are the model, the $\triangle \mathrm{AICC}$ value (difference between model AICc and the lowest AICc), the AIC weight of the model ( $\mathrm{w}$, which indicates the proportional support for this model), and a column summing those weights to $95 \%$ of total weight. fCORT: feather corticosterone value

\begin{tabular}{|lccc|}
\hline Model & AAICc & w & Sum w \\
\hline Foraging intensity & 0 & 0.379 & 0.379 \\
Null & 2.56 & 0.105 & 0.484 \\
Year & 2.64 & 0.101 & 0.585 \\
Fall $\delta^{15} \mathrm{~N}$ value & 3.15 & 0.0785 & 0.664 \\
Body size & 4.35 & 0.0430 & 0.707 \\
Sex & 4.42 & 0.0416 & 0.748 \\
Mean depth & 4.54 & 0.0391 & 0.787 \\
Home range area & 4.65 & 0.0370 & 0.824 \\
Spring $\delta^{15} \mathrm{~N}$ value & 4.76 & 0.0350 & 0.859 \\
Maximum distance from colony & 4.83 & 0.0338 & 0.893 \\
Fall fCORT level & 4.91 & 0.0324 & 0.926 \\
Spring fCORT level & 4.95 & 0.0319 & 0.958 \\
\hline
\end{tabular}

Table 3. Weighted parameter estimates for models of wintering variables and change in telomere length in the thickbilled murre. Presented are the parameter, the weighted estimate (based on models making up 95\% of Akaike's information criterion weight), and the weighted standard deviation (SD). Parameter estimates that do not overlap zero, indicating good predictive strength, are in bold

\begin{tabular}{|lcl|}
\hline Parameter & $\begin{array}{c}\text { Weighted } \\
\text { estimate }\end{array}$ & $\mathrm{SD}$ \\
\hline Intercept & 3.77 & 6.05 \\
Foraging intensity & $\mathbf{- 4 . 3 7}$ & $\mathbf{3 . 4 1}$ \\
Year (2009) & -1.12 & 1.44 \\
Fall $\delta^{15} \mathrm{~N}$ value & 0.408 & 0.551 \\
Body size & 0.244 & 0.387 \\
Sex (male) & 0.217 & 0.351 \\
Mean depth & 0.00922 & 0.0155 \\
Home range area & 0.000 & 0.000 \\
Spring $\delta^{15} \mathrm{~N}$ value & 0.0491 & 0.0952 \\
Maximum distance from colony & -0.00123 & 0.00263 \\
Fall fCORT level & 0.0122 & 0.0338 \\
Spring fCORT level & 0.0122 & 0.0457 \\
\hline
\end{tabular}

model having a higher $\triangle \mathrm{AICC}$ (year, $\triangle \mathrm{AICC}=4.02)$. Foraging intensity also remained the only parameter with a weighted estimate that did not overlap zero (weighted $\beta=-3.61 \pm 2.35$ ).

\section{Telomere change, wintering variables, and subsequent breeding (Prediction 3)}

Models with the lowest $\triangle \mathrm{AICc}$ for predicting breeding status in the recapture year $(0=$ non-breeding; 1 = breeding) were foraging intensity, body size, 


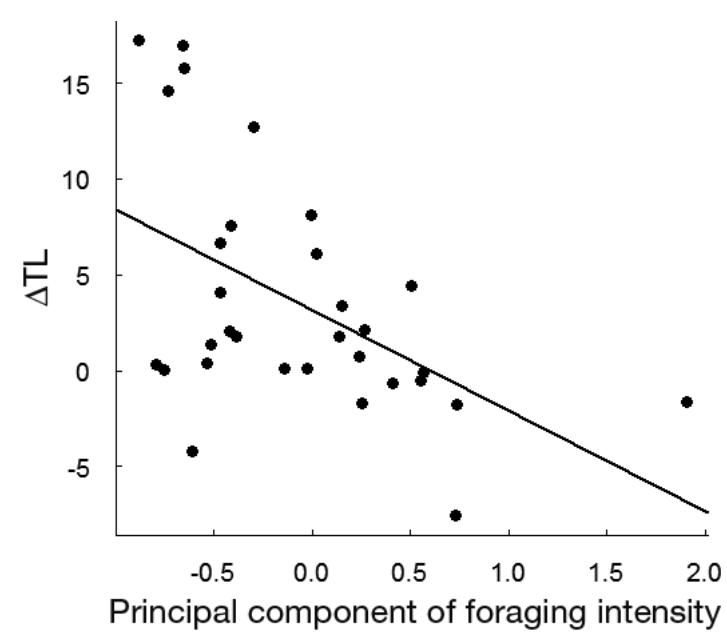

Fig. 2. Percent change in telomere length $(\Delta \mathrm{TL})$ from one breeding season to the next predicted by foraging intensity in the thick-billed murre. See Table 1 for details of the foraging intensity principal component

Table 4. AICc output for models predicting successful breeding in the thick-billed murre. See Table 2 for details

\begin{tabular}{|lccc|}
\hline Model & \multirow{2}{*}{ AICC } & w & Sum w \\
\hline Foraging intensity & 0 & 0.375 & 0.375 \\
Body size & 1.83 & 0.150 & 0.525 \\
Change in body mass & 2.57 & 0.104 & 0.629 \\
Null & 3.39 & 0.0688 & 0.698 \\
Year & 4.25 & 0.0448 & 0.742 \\
Fall fCORT level & 4.49 & 0.0397 & 0.782 \\
TL & 4.90 & 0.0323 & 0.814 \\
Maximum distance from colony & 4.94 & 0.0317 & 0.846 \\
Spring $\delta^{15}$ N value & 5.11 & 0.0291 & 0.875 \\
Spring fCORT level & 5.26 & 0.0270 & 0.902 \\
Home range area & 5.43 & 0.0248 & 0.927 \\
Sex & 5.58 & 0.0231 & 0.950 \\
\hline
\end{tabular}

and the change in mass (Table 4). However, all model-averaged parameter estimates overlapped zero (Table 5), indicating little influence of these variables on successful reproduction. Eliminating variables that did not perform well and limited the sample size allowed an increase to $\mathrm{n}=35$ but did not change the results (not shown).

\section{DISCUSSION}

\section{TL and wintering variables}

We found that deployment TL did not predict spatial wintering variables or foraging intensity but may be related to winter fCORT levels. Birds with longer
Table 5. Weighted parameter estimates for models predicting successful breeding in the thick-billed murre. Presented are the parameter, the weighted estimate (based on models making up 95\% of Akaike's information criterion weight), and the weighted standard deviation (SD). All parameter estimates overlap zero, indicating low predictive strength. fCORT: feather corticosterone value TL: telomere length

\begin{tabular}{|lcl|}
\hline Parameter & $\begin{array}{c}\text { Weighted } \\
\text { estimate }\end{array}$ & $\mathrm{SD}$ \\
\hline Intercept & 0.229 & 1.25 \\
Foraging intensity & -0.843 & 1.18 \\
Body size & 0.356 & 0.664 \\
Change in body mass & -0.000932 & 0.00184 \\
Year (2009) & -0.0568 & 0.125 \\
Fall fCORT level & -0.0104 & 0.0236 \\
TL & 0.00000790 & 0.0000189 \\
Maximum distance from colony & 0.000534 & 0.00129 \\
Spring $\delta^{15}$ N value & 0.0104 & 0.0262 \\
Spring fCORT level & -0.00713 & 0.0186 \\
Home range area & -0.000000124 & 0.000000350 \\
Sex (male) & 0.0114 & 0.0358 \\
\hline
\end{tabular}

TL had higher fCORT in the autumn (Fig. 1). Long TL may indicate high-quality individuals (Le Vaillant et al. 2015) that may have invested heavily in offspring, behaviorally or energetically. TL in murres is associated with breeding season foraging patterns, especially depth and choice of water masses (Young et al. 2015). Behavioral changes such as increased depth and trip duration led to higher post-breeding stress in rhinoceros auklets (Will et al. 2015), and similar patterns may drive post-breeding stress in murre fCORT as well. TL did not predict the location of wintering but may indicate individuals suffering carry-over effects from the breeding season, potentially due to lack of experience or high reproductive effort, although we cannot demonstrate a causal role for TL affecting fCORT.

\section{Overwinter behaviors and $\Delta \mathrm{TL}$}

Our second prediction was supported by the wintering data; foraging intensity, a principal component made up of diving-related behaviors, was a good predictor of $\Delta \mathrm{TL}$ (Tables $2 \& 3$ ). Murres with high foraging intensity scores (long bout duration, high percentage of time spent diving) lost more TL than those with lower scores. Birds with high foraging intensity may be inefficient foragers, recovering from stressful breeding seasons, or of lower quality, but their intense foraging is reflected in physiological changes to telomeres. However, spatial wintering variables (winter home range area and maximum distance from the colony) did not perform well as predictors of 
telomere change. Murres have extremely high wingloading and flight costs but are adept wing-propelled pursuit-diving foragers, specializing in catching agile, fast-moving prey underwater. Species-specific parameters related to the ability to extract energy from the environment should drive quality indicators, and telomeres were sensitive to these qualities, related to diving, in murres. Our findings support the idea that in a specialist diver, variation in water column use is more associated with TL maintenance than are flight patterns.

Although TL (and rates of change) have previously been shown to differ by sex and breeding colony in many species (reviewed in Barrett \& Richardson 2011) including the thick-billed murre (Young et al. 2013), such differences were not found in this study. However, male murres spend the first weeks after colony departure with the fledgling, diving intensely to supply both chick and self (Elliott \& Gaston 2014). Thus, telomere loss associated with intense foraging may contribute to the sex differences found in other studies. It should also be noted that, although many of our $\Delta \mathrm{TL}$ values were positive, a positive value is unlikely to be a true telomere lengthening (Steenstrup et al. 2013). Lengthening is likely due to short follow-up time (1 yr instead of many years in a longlived species) and also to methodological constraints. Therefore, we avoid interpreting a positive $\Delta \mathrm{TL}$ as an increase in TL but rather as TL maintenance or a reflection of relative differences in food availability or other conditions affecting those birds.

\section{$\Delta \mathrm{TL}$ and subsequent breeding}

TL and $\Delta$ TL were not associated with the probability of breeding in year 2. No parameter had an estimate that was different from zero, but models of foraging intensity and body size had $\triangle \mathrm{AICc}<2$. These models indicated that deployment year body mass was higher in birds that were breeding at recapture, and their overwinter foraging intensity was lower. This may indicate that the better condition of these birds carried over into the next year, although the results are not strong enough to make a definitive conclusion and certainly not strong enough to infer causation. We did find a relationship between $\Delta \mathrm{TL}$ and winter foraging intensity (previous subsection), but this did not carry over to breeding probability. Investigating longer time series of changes in foraging and breeding parameters, in relation to changes in body mass and $\Delta \mathrm{TL}$, would be a good subject for future research on drivers of carry-over effects.
There are 2 likely explanations for the lack of relationship between TL variables and subsequent breeding. It is possible that the birds which were not recaptured had extremely high TL loss, but variation in $\Delta \mathrm{TL}$ among recaptured birds was minimal, regardless of breeding status. Alternatively, as nonbreeding status may be due to parental quality or extrinsic causes, perhaps the murres recaptured as non-breeders are not the lowest-quality individuals, so their status is not associated with a quality indicator. It would be useful to assess fledging probability and adult survival in relation to TL and $\Delta$ TL. Perhaps on a scale of several years, the cumulative effect of winter stress and low trophic level diet will lead to fitness outcomes.

\section{CONCLUSION}

TL did not predict the spatial wintering patterns but may indicate individuals suffering high stress due to carry-over effects from the breeding season. Our findings also support the idea that telomeres, a physiological quality indicator, were sensitive to a species-specific parameter related to the ability to extract energy from the environment, in this case diving behaviors rather than spatial use. Winter foraging intensity was related to the maintenance of TL from year to year, although causation cannot be inferred. In this pursuit diver, variation in water column use was more important for maintaining TL than the size of the wintering area and distances travelled.

Acknowledgements. The authors are indebted to the BSIERP field crews on the Pribilof and Bogoslof Islands during 2008 to 2010, with special thanks to Rosana Paredes, Ann Harding, and Chris Barger. We also thank Evgenia Kitaiskaia for contributing to fCORT assays. fCORT analysis was funded by a North Pacific Research Board (NPRB) Graduate Student Research Award (GSRA) to A.P.W. Winter tracking and stable isotope analysis was supported by the USFWS, a NPRB GSRA to R.A.O., and NPRB project 911 (to David Irons, Daniel Roby, and Scott Shaffer). Work with birds was approved by the animal care and use committee of UCSC and the USFWS and by permit from the USFWS. The authors declare no conflict of interest.

\section{LITERATURE CITED}

Angelier F, Vleck CM, Holberton RL, Marra PP (2013) Telomere length, non-breeding habitat and return rate in male American redstarts. Funct Ecol 27:342-350

Barrett ELB, Richardson DS (2011) Sex differences in telomeres and lifespan. Aging Cell 10:913-921

Barrett ELB, Burke TA, Hammers M, Komdeur J, Richardson 
DS (2013) Telomere length and dynamics predict mortality in a wild longitudinal study. Mol Ecol 22:249-259

Bauch C, Becker PH, Verhulst S (2013) Telomere length reflects phenotypic quality and costs of reproduction in a long-lived seabird. Proc R Soc B 280:20122540

Becker BH, Newman SH, Inglis S, Beissinger SR (2007) Diet-feather stable isotope $\left(\delta^{15} \mathrm{~N}\right.$ and $\left.\delta^{13} \mathrm{C}\right)$ fractionation in common murres and other seabirds. Condor 109:451-456

Bortolotti GR, Marchant TA, Blas J, German T (2008) Corticosterone in feathers is a long-term, integrated measure of avian stress physiology. Funct Ecol 22:494-500

* Bourgeon S, Leat EHK, Magnusdóttir E, Furness RW and others (2014) Feather corticosterone levels on wintering grounds have no carry-over effects on breeding among three populations of great skuas (Stercorarius skua). PLOS ONE 9:e100439

* Drake A, Rock C, Quinlan SP, Green DG (2013) Carry-over effects of winter habitat vary with age and sex in yellow warblers Setophaga petechia. J Avian Biol 44:321-330

Elliott KH, Gaston AJ (2014) Dive behaviour and daily energy expenditure in thick-billed murres Uria lomvia after leaving the breeding colony. Mar Ornithol 42: 183-189

Elliott KH, Ricklefs RE, Gaston AJ, Hatch SA, Speakman JR, Davoren GK (2013) High flight costs, but low dive costs, in auks support the biomechanical hypothesis for flightlessness in penguins. Proc Natl Acad Sci USA 110: 9380-9384

Gaston AJ, Jones IL (1998) Bird families of the world: the auks (Alcidae). Oxford University Press, Oxford

* González-Prieto AM, Hobson KA (2013) Environmental conditions on wintering grounds and during migration influence spring nutritional condition and arrival phenology of neotropical migrants at a northern stopover site. J Ornithol 154:1067-1078

KHarding AMA, Paredes R, Suryan R, Roby D and others (2013) Does location really matter? An inter-colony comparison of seabirds breeding at varying distances from productive oceanographic features in the Bering Sea. Deep-Sea Res II 94:178-191

* Holmes RT (2007) Understanding population change in migratory songbirds: long-term and experimental studies of neotropical migrants in breeding and wintering areas. Ibis 149:2-13

Inger R, Harrison XA, Ruxton GD, Newton J and others (2010) Carry-over effects reveal reproductive costs in a long-distance migrant. J Anim Ecol 79:974-982

Karnovsky NJ, Hobson KA, Iverson SJ (2012) From lavage to lipids: estimating diets of seabirds. Mar Ecol Prog Ser 451:263-284

Kitaysky AS, Piatt JF, Wingfield JC (2007) Stress hormones link food availability and population processes in seabirds. Mar Ecol Prog Ser 352:245-258

Kokubun N, Yamamoto T, Sato NN, Watanuki Y, Will AP, Kitaysky AS, Takahashi A (2016) Foraging segregation of two congeneric diving seabird species breeding on St. George Island, Bering Sea. Biogeosciences 13:2579-2591

Koren L, Nakagawa S, Burke TA, Soma KK, WynneEdwards KE, Geffen E (2012) Non-breeding feather concentrations of testosterone, corticosterone and cortisol are associated with subsequent survival in wild house sparrows. Proc R Soc B 279:1560-1566

Kattin CR, Reed JM, DesRochers DW, Romero LM (2011) Elevated corticosterone in feathers correlates with corticosterone-induced decreased feather quality: a vali- dation study. J Avian Biol 42:247-252

* Le Vaillant M, Viblanc VA, Saraux C, Le Bohec C and others (2015) Telomere length reflects individual quality in free-living adult king penguins. Polar Biol 38:2059-2067

* Luque SP, Guinet C (2007) A maximum likelihood approach for identifying dive bouts improves accuracy, precision and objectivity. Behaviour 144:1315-1332

Monaghan P (2010) Telomeres and life histories: the long and the short of it. Ann N Y Acad Sci 1206:130-142

* Monaghan P, Haussmann MF (2006) Do telomere dynamics link lifestyle and lifespan? Trends Ecol Evol 21:47-53

* Morrissette M, Bêty J, Gauthier G, Reed A, Lefebvre J (2010) Climate, trophic interactions, density dependence and carry-over effects on the population productivity of a migratory Arctic herbivorous bird. Oikos 119:1181-1191

Nehls G (1996) Low costs of salt turnover in common eiders Somateria mollissima. Ardea 84:23-30

Norris DR, Taylor CM (2006) Predicting the consequences of carry-over effects for migratory populations. Biol Lett 2: 148-151

O'Connor CM, Norris DR, Crossin GT, Cooke SJ (2014) Biological carryover effects: linking common concepts and mechanisms in ecology and evolution. Ecosphere 5:28

Orben RA, Paredes R, Roby DD, Irons DB, Shaffer SA (2015) Body size affects individual winter foraging strategies of thick-billed murres in the Bering Sea. J Anim Ecol 84: 1589-1599

* Pauliny A, Wagner RH, Augustin J, Szep T, Blomqvist D (2006) Age-independent telomere length predicts fitness in two bird species. Mol Ecol 15:1681-1687

*Pauliny A, Larsson K, Blomqvist D (2012) Telomere dynamics in a long-lived bird, the barnacle goose. BMC Evol Biol 12:257

* Plot V, Criscuolo F, Zahn S, Georges JY (2012) Telomeres, age and reproduction in a long-lived reptile. PLOS ONE 7:e408555

R Development Core Team (2011) R: a language and environment for statistical computing. R Foundation for Statistical Computing, Vienna

米Reudink MW, Marra PP, Kyser TK, Boag PT, Langin KM, Ratcliffe LM (2009) Non-breeding season events influence sexual selection in a long-distance migratory bird. Proc Roy Soc B 276:1619-1626

Rockwell SM, Bocetti CI, Marra PP (2012) Carry-over effects of winter climate on spring arrival date and reproductive success in an endangered migratory bird, Kirtland's warbler (Setophaga kirtlandii). Auk 129:744-752

* Salomons HM, Mulder GA, van de Zande L, Haussmann MF, Linskens MHK, Verhulst S (2009) Telomere shortening and survival in free-living corvids. Proc R Soc B 276: 3157-3165

* Sanderson JL, Young AJ, Hodge SJ, Kyabulima S, Walker SL, Cant MA (2014) Hormonal mediation of a carry-over effect in a wild cooperative mammal. Funct Ecol 28: 1377-1386

Schultner J, Moe B, Chastel O, Bech C, Kitaysky AS (2014a) Migration and stress during reproduction govern telomere dynamics in a seabird. Biol Lett 10:20130889

* Schultner J, Moe B, Chastel O, Tartu S, Bech C, Kitaysky AS (2014b) Corticosterone mediates carry-over effects between breeding and migration in the kittiwake Rissa tridactyla. Mar Ecol Prog Ser 496:125-133

Sorensen MC, Hipfner JM, Kyser TK, Norris DR (2009) Carry-over effects in a Pacific seabird: stable isotope evidence that pre-breeding diet quality influences repro- 
ductive success. J Anim Ecol 78:460-467

Steenstrup T, Hjelmborg JvB, Kark JD, Christensen K, Aviv A (2013) The telomere lengthening conundrum - artifact or biology? Nucleic Acids Res 41:e131

Stutchbury BJ, Gow EA, Done T, MacPherson M, Fox JW, Afanasyev V (2011) Effects of post-breeding moult and energetic condition on timing of songbird migration into the tropics. Proc R Soc B 278:131-137

Sudyka J, Arct A, Drobniak S, Dubiec A, Gustafsson L, Cichon M (2014) Experimentally increased reproductive effort alters telomere length in the blue tit (Cyanistes caeruleus). J Evol Biol 27:2258-2264

Takahashi A, Ito M, Suzuki Y, Watanuki Y and others (2015) Migratory movements of rhinoceros auklets in the northwestern Pacific: connecting the seasonal productivities. Mar Ecol Prog Ser 525:229-243

von Zglinicki T (2002) Oxidative stress shortens telomeres. Trends Biochem Sci 27:339-344

Will A, Watanuki Y, Kikuchi DM, Sato NN and others (2015)

Editorial responsibility: Richard Phillips (Guest Editor), Cambridge, UK
Feather corticosterone reveals stress associated with dietary changes in a breeding seabird. Ecol Evol 5: 4221-4232

* Wingfield JC, Farner DS (1975) The determination of five steroids in avian plasma by radioimmunoassay and competitive protein-binding. Steroids 26:311-327

* Young RC, Kitaysky AS, Haussmann MF, Descamps S, Orben R, Elliott KH, Gaston AJ (2013) Age, sex, and telomere dynamics in a long-lived seabird with malebiased parental care. PLOS ONE 8:e74931

Y Young RC, Kitaysky AS, Barger CP, Dorresteijn I, Ito M, Watanuki Y (2015) Telomere length is a strong predictor of foraging behavior in a long-lived seabird. Ecosphere 6:39

* Young RC, Barger CP, Dorresteijn I, Haussmann MF, Kitaysky AS (2016) Telomere length and environmental conditions predict stress levels but not parental investment in a long-lived seabird. Mar Ecol Prog Ser 556: 251-259

Submitted: May 9, 2016; Accepted: December 16, 2016 Proofs received from author(s): February 12, 2017 